\title{
Comparison of Emotional Intelligence Levels of Students Studying in Summer School of Physical Education and Sports with Their Life Satisfaction
}

\author{
Nahit Özdayi ${ }^{1}$, Ali Serdar Yücel ${ }^{2}$, Mehmet Burak Demir ${ }^{3}$ \\ ${ }^{1}$ Balıkesir University, Department of Coaching Education Balıkesir / Turkey \\ ${ }^{2}$ Frrat University, Faculty of Sports Sciences, Elazı $\breve{g} /$ Turkey \\ ${ }^{3}$ Directorate of National Education, Physical Education Teacher, Elazığ / Turkey \\ Correspondence: Ali Serdar Yücel, Firat University, Faculty of Sports Sciences, Elazı̆ğ / Turkey.
}

Received: January 28, 2019

doi:10.11114/jets.v7i3.4104

\author{
Accepted: February 19, $2019 \quad$ Online Published: February 26, 2019 \\ URL: https://doi.org/10.11114/jets.v7i3.4104
}

\begin{abstract}
The purpose of this study is to compare emotional intelligence levels of students studying in 2017-2018 summer school of Balıkesir University School of Physical Education and Sports with their life satisfaction by some demographic characteristics. This is a descriptive study. The research population is composed of 865 students studying in 2017-2018 summer school of Balıkesir University School of Physical Education and Sports and the sample is composed of randomly selected 292 students. In the study, "Emotional Intelligence Inventory in Sports" developed by Shutte et al. (1998), revised and adapted by Lane et al. (2009) for use in sports with Turkish reliability and validity performed by Adiloğulları and Görgülü (2015) and 5-point Likert type scale "The Satisfaction with Life Scale (SWLS)" developed by Diener et al. (1985) with the purpose of determining the life satisfaction of people and adapted into Turkish by Durak et al. (2010) were used. General reliability value of emotional intelligence scale was found as $\alpha=0.927$ and the same value of life satisfaction scale was determined as $\alpha=0.819$, indicating a high level of reliability. Anova, Kruskal Wallis test, Jonckheere-Terpstra test were used in data analysis. All analyses were conducted with SPSS v17.0 (SPSS Science, Chicago, IL, USA).

In conclusion, it has been determined that emotional intelligence levels of the participants differ by the variable of age in the dimension of use of emotions, by the variable of department in the dimensions of evaluation of one's own feelings and social skills and there is a difference by the variable of age regarding life satisfaction. It has also been established that there isn't any relation between the emotional intelligence levels and life satisfaction of individuals.
\end{abstract}

Keywords: emotional intelligence, student, sports

\section{Introduction}

\section{Emotional Intelligence from Conceptual Perspective}

Emotional intelligence occurs in direct relation to the establishment of a mental and spiritual balance. A person's perspective on events, positive thinking, and ability to solve problems ensure a balance in one's life and activities related to emotional intelligence capability. Thus, one gains the power to have self-confidence, to focus on success, to solve problems and to become aware of one's own abilities to communicate with other individuals (Harrod and Scheer, 2005).

\section{Emotional Intelligence and Athletic Skills}

The positive effects of emotional intelligence on athletic skills in athletes are due to the athletes' own optimism (Malinauskas and Vazne, 2014). It can be considered that emotional intelligence may affect athletic skills and athletic skills may also be influenced by emotional intelligence vice versa. Levels of arousal and emotion control are developing in sports branches that require ambition (Szabo and Urban, 2014). One of the discourses of the coaches is the potential impact of the factors that help to develop emotional control techniques on athletic performance (Jones, 2003). Coaches without the ability to manage and understand emotions can also lead to fragile success (Haime, 2011). 


\section{Characteristics of Emotional Intelligence}

Self-awareness, Autocontrol, Motivation, Empathy and Human Relations are five different phenomena that have an impact on the emergence of emotional intelligence (Çetinkaya and Alparslan, 2011).

Emotional intelligence begins with the individual's self and continues with her/his communication with the environment. Therefore, the correct, positive and permanent steps to be taken at the beginning are the only actions for the individual to survive in every aspect of her/his life. The responses need to be given for the required time periods allow the individual to continue her/his path continuously (Lopes et al. 2004).

Generally accepted characteristics of emotional intelligence can be listed as follows (Goleman, 1996):

- As the perceptions of individuals become stronger and their emotions become clearer as a result of their focus on a particular subject and their emotional intelligence, the effectiveness of emotional intelligence on the decision mechanism and attitude and behaviors of individuals increases.

- Emotional intelligence and logic levels of individuals acting with emotional intelligence is equivalent to each other; even in the course of time, the higher level of loyalty of individuals to their emotional intelligence precludes the concept of logic.

- Emotional intelligence is mostly based on emotions and thoughts that have the strongest influence on the attitudes and behaviors of the individual.

- Emotional intelligence is largely a reflection of the elements within the spiritual world of the individual into practice.

\section{Factors Effective in Development Process of Emotional Intelligence}

Age, Sex, Family and Environment are factors that indirectly affect the development of emotional intelligence although they remain in the background (Tuğrul, 1999).

\section{Life Satisfaction}

Life satisfaction represents the cognitive aspect of subjective well-being related to one's happiness. Subjective well-being encompasses the individual's life in emotional and personal aspects and her/his emotional reactions to events and the cognitive assessment of life satisfaction (Diener, 1984).

Happiness encountered in everyday life frequently is a concept that is difficult to define and denotes various meanings. Thus, social psychologists use "life satisfaction and subjective well-being" concepts instead of happiness (Özer and Karabulut, 2003).

\section{Factors Affecting Life Satisfaction}

Life satisfaction is defined as the quality of the society as a whole, the role of the individual in society, her/his existing abilities, the progress of life events, being experienced, concluding with internal development, researching the meaning of emotions and expressing the relationship between life satisfaction and satisfaction area (Veenhoven,1996).

Depending on the different level of perception of life satisfaction from individual to individual, there is an uncertainty in defining and establishing the concept. Factors affecting life satisfaction are listed as follows to better understand the concept (Yetim, 2003):

1. Being happy with everyday life

2. Finding life meaningful

3. Compliance with reaching to targets

4. Positive personal identity

5. Physical well-being of person

6. Economic safety

7. Social relations.

\section{Material and Method}

\section{Research Population and Sample}

Data were obtained from 292 participants among 865 students studying in 2017-2018 Summer school of Balıkesir University School of Physical Education and Sports. 


\section{Data Collection Tool}

"Emotional Intelligence Inventory in Sports" developed by Schutte et al. (1998) and revised and adapted by Lane et al. (2009) for use in sports was used as emotional intelligence scale. The validity and reliability of Turkish version was performed by Adiloğulları and Görgülü (2015). The scale consists of 19 items and five sub-dimensions, including evaluating others' feelings, evaluating one's own feelings, regulating emotions, social skills and using feelings. Emotional intelligence inventory in sports was applied to a total of 404 (age $=20.80 \pm 2.17$ years) athletes composed of 157 females and 247 males. Adiloğulları and Görgülü found the internal consistency coefficient of the scale as 0.91 .

The Satisfaction with Life Scale (SWLS) was developed by Deiner et al. (1985) in order to determine the life satisfaction of individuals. Following the reliability analyses performed related to the scale, Cronbach Alpha coefficient was calculated as .87. The scale was adopted into Turkish by Durak et al. (2010). It is a 5-point Likert type scale composed of 5 items. Following the reliability analyses performed in the study, Cronbach Alpha coefficient was calculated as 0.819 . General reliability of the emotional intelligence scale was found as $\alpha=0.927$ in this study, which indicates a high level reliability.

\section{Data Analysis}

$\mathrm{p}<0.05$ was taken into account when calculating statistical differences between groups. Factor analysis was used to confirm emotional intelligence and life satisfaction scales.

Basic components and cyclic factor analysis method were used to evaluate emotional intelligence and life satisfaction scales. In emotional intelligence questionnaire, distribution of 19 questions were evaluated by the sub-dimensions of "Evaluating others' feelings", "Evaluating one's own feelings", "Regulating emotions", "Social skills" and "Using feelings". The suitability of the data to the factor analysis was assessed with the Bartlett test and the suitability of the magnitude of research group was evaluated with the Keizer-Meyer-Olkin coefficient. Internal consistency of the questionnaire was evaluated with the Cronbach's Alpha coefficients obtained for each sub-dimension. Anova, Kruskal Wallis test and Jonckheere-Terpstr test were used in data analysis. All analyses were performed with SPSS v17.0 (SPSS Science, Chicago, IL, USA).

\section{Findings}

In this part, data obtained from the participants are interpreted and supported with tables.

Table 1. Descriptive Statistics of the Participants

\begin{tabular}{l|l|l|l}
\hline \multicolumn{2}{l}{ Variables } & \multicolumn{1}{|l|}{ Count } & Column N \% \\
\cline { 2 - 4 } Age & $22-21$ & 99 & $34 \%$ \\
\cline { 2 - 4 } & $26+$ & 132 & $45 \%$ \\
\hline \multirow{3}{*}{ Sex } & Male & 61 & $21 \%$ \\
\cline { 2 - 4 } & Female & 0 & $0 \%$ \\
\hline \multirow{3}{*}{ Sports Branch } & Team sports & 292 & $100 \%$ \\
\cline { 2 - 4 } & Individual sports & 90 & $31 \%$ \\
\cline { 2 - 4 } & No & 202 & $69 \%$ \\
\hline \multirow{5}{*}{ Department } & Coaching education & 0 & $0 \%$ \\
\cline { 2 - 4 } & Physical education and sports teaching & 108 & $37 \%$ \\
\cline { 2 - 4 } & Sports management & 94 & $32 \%$ \\
\hline \multirow{3}{*}{ Grade } & 1 & 90 & $31 \%$ \\
\cline { 2 - 4 } & 2 & 50 & $17 \%$ \\
\cline { 2 - 4 } & 3 & 60 & $21 \%$ \\
\cline { 2 - 4 } & 4 & 92 & $32 \%$ \\
\hline
\end{tabular}

- All of the participant students are female, 34\% of them are 18-21 years of age, $45 \%$ are $22-25$ years of age and $21 \%$ are aged above 26 .

- As sports branch, $31 \%$ of them are in team sports and $69 \%$ of them are in individual sports.

- $\quad 37 \%$ of them receive coaching education, $32 \%$ receive physical education and sports teaching and $31 \%$ receive sports management education.

- $\quad 17 \%$ of them are first grade students, $21 \%$ are in the second grade, $32 \%$ are in the third grade and $31 \%$ are the fourth grade students.

\section{Factor Analysis}

Factor analysis was performed via data obtained from 292 students. Bartlett test evaluating the compliance of data with the factor analysis was found as p<0.001 and Kaiser- Meyer- Olkin (KMO) coefficient as 0.896 (high). 
Table 2. KMO and Bartlett's Test

\begin{tabular}{lll}
\hline \multicolumn{2}{l}{ Kaiser-Meyer-Olkin Measure of Sampling Adequacy. } & .896 \\
Bartlett's Test of Sphericity & Approx. Chi-Square & 4296.229 \\
& Df & 171 \\
& Sig. & .000 \\
\hline
\end{tabular}

Table 3. Factor Loads Regarding Scale Items

\begin{tabular}{|c|c|c|c|c|c|c|}
\hline & 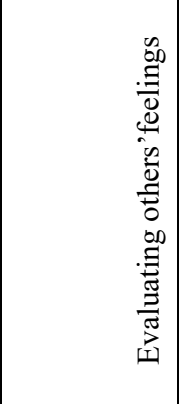 & 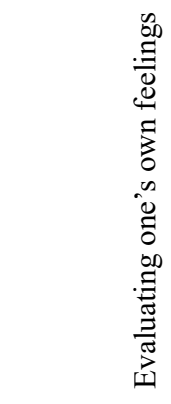 & 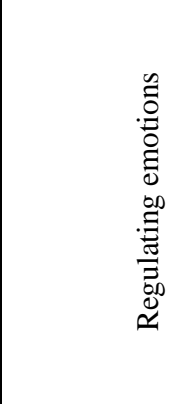 & 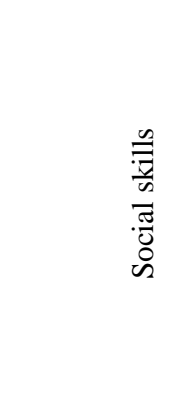 & 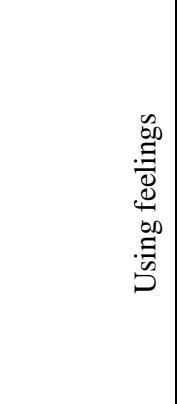 & 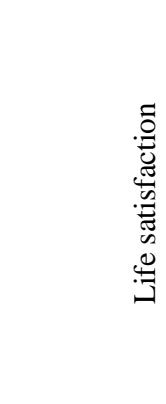 \\
\hline $\begin{array}{l}\text { I can tell how people feel by looking at their } \\
\text { facial expressions. } \\
\text { When someone tells me an important event about } \\
\text { her/his life, I feel as if I experienced that event } \\
\text { myself. } \\
\text { I can tell what people feel only by looking at their } \\
\text { facial expressions. } \\
\text { It's hard for me to understand why people feel } \\
\text { that way. } \\
\text { I can tell how people feel themselves by listening } \\
\text { to their voice. } \\
\text { I become aware of my feelings as I experience } \\
\text { them. } \\
\text { I actually know why my feelings have changed. } \\
\text { I easily recognize my feelings as I feel them. } \\
\text { I have control over my feelings. } \\
\text { I seek and find the activities that make me happy. } \\
\text { I enjoy sharing my feelings with others. } \\
\text { I organize activities that others will enjoy. } \\
\text { I help other people when they are sad to make } \\
\text { them feel better. } \\
\text { I see new possibilities when my mood changes. } \\
\text { I know how to sustain a positive feeling when I } \\
\text { live it. } \\
\text { Solving problems is easy for me when I am in a } \\
\text { good mood. } \\
\text { I can find new ideas when my mood is positive. } \\
\text { I am inclined to find new ideas when I feel a } \\
\text { change in my feelings. } \\
\text { I use my good moods in order to sustain my } \\
\text { determination against obstacles. } \\
\text { I live a life close to my ideals in many ways. } \\
\text { My living conditions are perfect. } \\
\text { My life satisfies me. } \\
\text { Until now, I have achieved important things in } \\
\text { my life. } \\
\text { If I had a chance to live my life again, I would } \\
\text { change almost nothing. }\end{array}$ & $\begin{array}{l}.679 \\
.562 \\
.411 \\
.926 \\
.628\end{array}$ & $\begin{array}{l}.733 \\
.821 \\
.634\end{array}$ & $\begin{array}{l}.901 \\
.684\end{array}$ & $\begin{array}{l}.814 \\
.681 \\
.399\end{array}$ & $\begin{array}{l}.580 \\
.727 \\
\\
.863 \\
\\
.620 \\
.653 \\
.554\end{array}$ & $\begin{array}{l} \\
.802 \\
.657 \\
.628 \\
.544 \\
.332\end{array}$ \\
\hline
\end{tabular}

The results of factor loads obtained for each question are summarized in Table 3. The five questions asked for the factor of evaluating the emotions of others are collected under this group. Three questions asked for the factor of evaluating one's own feelings are collected under this group. Two questions asked for the factor of regulating emotions are collected under this group. Three questions asked for the social skills factor are collected under this group. Six questions 
asked for the factor of use of emotions are under this group. Five questions asked for life satisfaction factor are collected under this group.

Table 4. Subtitles of Scale and Mean, Standard Deviation and Cronbach's Alpha Values for Emotional Intelligence and Life Satisfaction

\begin{tabular}{|c|c|c|c|c|c|c|}
\hline & \multicolumn{2}{|c|}{ Reliability Statistics } & \multicolumn{4}{|c|}{ Scale Statistics } \\
\hline & $\begin{array}{l}\text { Cronbach's } \\
\text { Alpha }\end{array}$ & $\begin{array}{l}\text { Cronbach's Alpha } \\
\text { Based on } \\
\text { Standardized Items } \\
\end{array}$ & Mean & Variance & $\begin{array}{l}\text { Std. } \\
\text { Deviation }\end{array}$ & $\begin{array}{l}\mathrm{N} \text { of } \\
\text { Items }\end{array}$ \\
\hline EVALUATING OTHERS' FEELINGS & .583 & .614 & 16.8219 & 10.717 & 3.27373 & 5 \\
\hline EVALUATING ONE'S OWN FEELINGS & .891 & .892 & 10.8767 & 9.923 & 3.15006 & 3 \\
\hline REGULATING EMOTIONS & .737 & .738 & 7.5616 & 3.244 & 1.80100 & 2 \\
\hline SOCIAL SKILLS & .759 & .760 & 10.3493 & 7.981 & 2.82500 & 3 \\
\hline USING FEELINGS & .924 & .924 & 21.6370 & 33.799 & 5.81369 & 6 \\
\hline LIFE SATISFACTION & .819 & .823 & 16.4110 & 19.377 & 4.40192 & 5 \\
\hline
\end{tabular}

Mean, standard deviation and Cronbach's alpha values obtained for subtitles of the scale and emotional intelligence and life satisfaction are summarized in Table 4. Mean Cronbach's Alpha value is 0.583 for evaluating others' feelings, 0.891 for evaluating one's own feelings, 0.737 for regulating emotions, 0.759 for social skills, 0.924 for using feelings and 0.819 for life satisfaction.

Table 5. Total Variance Analysis Results of the Scale

\begin{tabular}{|c|c|c|c|c|c|c|c|c|c|}
\hline \multirow[t]{2}{*}{ Component } & \multicolumn{3}{|c|}{ Initial Eigenvalues } & \multicolumn{3}{|c|}{$\begin{array}{llll}\begin{array}{l}\text { Extraction } \\
\text { Loadings }\end{array} & \text { Sums of } & \text { Squared } \\
\end{array}$} & \multicolumn{3}{|c|}{ Rotation Sums of Squared Loadings } \\
\hline & Total & $\begin{array}{l}\% \text { of } \\
\text { Variance }\end{array}$ & Cumulative $\%$ & Total & $\begin{array}{l}\% \text { of } \\
\text { Variance }\end{array}$ & Cumulative $\%$ & Total & $\begin{array}{l}\% \text { of } \\
\text { Variance }\end{array}$ & Cumulative \% \\
\hline 1 & 9.933 & 52.281 & 52.281 & 9.933 & 52.281 & 52.281 & 4.378 & 23.041 & 23.041 \\
\hline 2 & 1.238 & 6.516 & 58.797 & 1.238 & 6.516 & 58.797 & 3.362 & 17.697 & 40.738 \\
\hline 3 & 1.129 & 5.940 & 64.737 & 1.129 & 5.940 & 64.737 & 2.097 & 11.039 & 51.778 \\
\hline 4 & .974 & 5.126 & 69.863 & .974 & 5.126 & 69.863 & 2.042 & 10.748 & 62.525 \\
\hline 5 & .922 & 4.851 & 74.714 & .922 & 4.851 & 74.714 & 1.919 & 10.098 & 72.623 \\
\hline 6 & .795 & 4.182 & 78.896 & .795 & 4.182 & 78.896 & 1.192 & 6.273 & 78.896 \\
\hline
\end{tabular}

The scale explains the total variance of emotional intelligence and life satisfaction as $78 \%$. The contribution of the sub-dimensions of the scale to the total variance is $23 \%$ for evaluating others' feelings, $17 \%$ for evaluating one's own feelings, $11 \%$ for regulating emotions, $10 \%$ for social skills, $10 \%$ for using feelings and $6 \%$ for life satisfaction.

Table 6. Anova Test Results for the Variable of Age

\begin{tabular}{|c|c|c|c|c|c|c|}
\hline & & $\begin{array}{c}\text { Sum of } \\
\text { Squares }\end{array}$ & df & $\begin{array}{c}\text { Mean } \\
\text { Square }\end{array}$ & $\mathrm{F}$ & Sig. \\
\hline \multirow[t]{3}{*}{ EVALUATING OTHERS' FEELINGS } & Between Groups & 50.582 & 2 & 25.291 & 2.382 & .094 \\
\hline & Within Groups & 3068.158 & 289 & 10.616 & & \\
\hline & Total & 3118.740 & 291 & & & \\
\hline \multirow[t]{3}{*}{ EVALUATING ONE'S OWN FEELINGS } & Between Groups & 57.889 & 2 & 28.945 & 2.956 & .054 \\
\hline & Within Groups & 2829.672 & 289 & 9.791 & & \\
\hline & Total & 2887.562 & 291 & & & \\
\hline \multirow[t]{3}{*}{ REGULATING EMOTIONS } & Between Groups & 11.100 & 2 & 5.550 & 1.719 & .181 \\
\hline & Within Groups & 932.791 & 289 & 3.228 & & \\
\hline & Total & 943.890 & 291 & & & \\
\hline \multirow[t]{3}{*}{ SOCIAL SKILLS } & Between Groups & 15.009 & 2 & 7.505 & .940 & .392 \\
\hline & Within Groups & 2307.360 & 289 & 7.984 & & \\
\hline & Total & 2322.370 & 291 & & & \\
\hline \multirow[t]{3}{*}{ USING FEELINGS } & Between Groups & 339.935 & 2 & 169.967 & 5.173 & .006 \\
\hline & Within Groups & 9495.586 & 289 & 32.857 & & \\
\hline & Total & 9835.521 & 291 & & & \\
\hline \multirow[t]{3}{*}{ LIFE SATISFACTION } & Between Groups & 149.499 & 2 & 74.750 & 3.935 & .021 \\
\hline & Within Groups & 5489.186 & 289 & 18.994 & & \\
\hline & Total & 5638.685 & 291 & & & \\
\hline
\end{tabular}

Anova test will be applied in order to understand whether emotional intelligence and life satisfaction differs by age. Anova test results will be used to determine whether there is a difference between the answers given to the emotional intelligence and life satisfaction scale among ages. The main hypothesis of the analysis asserts that there is no difference between ages. The possibility value calculated after the test (Sig) was found to be higher than 0.05 excluding only two factors. The main hypotheses of these two factors will be rejected. The results are as follows; 
- The factor of evaluating others' feelings doesn't differ by age.

- The factor of evaluating one's own feelings doesn't differ by age.

- The factor of regulating emotion doesn't differ by age.

- The factor of social skills doesn't differ by age.

- The factor of social skills doesn't differ by age.

- The factor of using feelings differs by age. The mean value of 26+ age group is the lowest and the highest value belongs to $18-21$ age group.

- The factor of life satisfaction differs by age. The mean value of 18-21 age group is the lowest and the highest value belongs to $26+$ age group.

Table 7. Descriptive Analyses for the Variable of Age

\begin{tabular}{|c|c|c|c|}
\hline Dimensions & \begin{tabular}{|c|} 
Mean \\
$18-21$
\end{tabular} & $22-25$ & 26+ \\
\hline EVALUATING OTHERS' FEELINGS & 17.09 & 16.99 & 16.02 \\
\hline EVALUATING ONE'S OWN FEELINGS & 10.83 & 11.27 & 10.10 \\
\hline REGULATING EMOTIONS & 7.73 & 7.61 & 7.20 \\
\hline SOCIAL SKILLS & 10.53 & 10.42 & 9.92 \\
\hline USING FEELINGS & 22.79 & 21.63 & 19.79 \\
\hline LIFE SATISFACTION & 15.46 & 16.70 & 17.31 \\
\hline
\end{tabular}

The mean values regarding the variable of age are observed in Table 7.

Table 8. Kruskal Wallis Test for Sports Branches

\begin{tabular}{|c|c|c|c|}
\hline Dimensions & Chi-square & df & Asymp. Sig \\
\hline EVALUATING OTHERS' FEELINGS & 3.625 & 1 & .057 \\
\hline EVALUATING ONE'S OWN FEELINGS & .012 & 1 & .913 \\
\hline REGULATING EMOTIONS & .441 & 1 & .506 \\
\hline SOCIAL SKILLS & 1.252 & 1 & .263 \\
\hline USING FEELINGS & .626 & 1 & .429 \\
\hline LIFE SATISFACTION & 1.467 & 1 & .226 \\
\hline
\end{tabular}

Kruskal Wallis test will be applied to determine whether emotional intelligence and life satisfaction scale differs by the sports branches. Kruskal Wallis test results will be used to determine whether there is a difference between the answers given to the emotional intelligence and life satisfaction scale among sports branches. The main hypothesis of the analysis asserts that there is no difference between sports branches. The possibility value calculated after the test (Sig) was found to be higher than 0.05 for all factors. The main hypotheses of all factors cannot be rejected. The results are as follows;

- The factor of evaluating others' feelings doesn't differ by sports branches.

- The factor of evaluating one's own feelings doesn't differ by sports branches.

- The factor of regulating emotion doesn't differ by sports branches.

- The factor of social skills doesn't differ by sports branches.

- The factor of social skills doesn't differ by sports branches.

- The factor of using feelings doesn't differ by sports branch.

- The factor of life satisfaction doesn't differ by sports branches.

Table 9. Descriptive Analyses for the Sports Branches

\begin{tabular}{|c|c|c|}
\hline \multirow[b]{2}{*}{ Dimensions } & \multicolumn{2}{|c|}{ Mean } \\
\hline & Team sports & Individual sports \\
\hline EVALUATING OTHERS' FEELINGS & 17.42 & 16.55 \\
\hline EVALUATING ONE'S OWN FEELINGS & 11.27 & 10.70 \\
\hline REGULATING EMOTIONS & 7.38 & 7.64 \\
\hline SOCIAL SKILLS & 10.78 & 10.16 \\
\hline USING FEELINGS & 21.96 & 21.50 \\
\hline LIFE SATISFACTION & 16.82 & 16.23 \\
\hline
\end{tabular}

The mean values regarding the variable of sports branches are observed in Table 9. 
Table 10. Anova Test Results for Departments

\begin{tabular}{|c|c|c|c|c|c|c|}
\hline & & $\begin{array}{c}\text { Sum of } \\
\text { Squares }\end{array}$ & df & $\begin{array}{c}\text { Mean } \\
\text { Square }\end{array}$ & $\mathrm{F}$ & Sig \\
\hline \multirow{3}{*}{ Evaluating Others' Feelings } & \begin{tabular}{|l|} 
Between Groups \\
\end{tabular} & 22.928 & 2 & 11.464 & 1.070 & .344 \\
\hline & Within Groups & 3095.811 & 289 & 10.712 & & \\
\hline & Total & 3118.740 & 291 & & & \\
\hline \multirow[t]{3}{*}{ Evaluating One's Own Feelings } & Between Groups & 86.869 & 2 & 43.435 & 4.482 & .012 \\
\hline & Within Groups & 2800.692 & 289 & 9.691 & & \\
\hline & Total & 2887.562 & 291 & & & \\
\hline \multirow[t]{3}{*}{ Regulating Emotions } & Between Groups & 2.213 & 2 & 1.107 & .340 & .712 \\
\hline & Within Groups & 941.677 & 289 & 3.258 & & \\
\hline & Total & 943.890 & 291 & & & \\
\hline \multirow[t]{3}{*}{ Social Skills } & Between Groups & 65.801 & 2 & 32.901 & 4.214 & .016 \\
\hline & Within Groups & 2256.569 & 289 & 7.808 & & \\
\hline & Total & 2322.370 & 291 & & & \\
\hline \multirow[t]{3}{*}{ Using Feelings } & Between Groups & 68.747 & 2 & 34.374 & 1.017 & .363 \\
\hline & Within Groups & 9766.773 & 289 & 33.795 & & \\
\hline & \begin{tabular}{|l|} 
Total \\
\end{tabular} & 9835.521 & 291 & & & \\
\hline \multirow[t]{3}{*}{ Life Satisfaction } & Between Groups & 53.678 & 2 & 26.839 & 1.389 & .251 \\
\hline & Within Groups & 5585.007 & 289 & 19.325 & & \\
\hline & Total & 5638.685 & 291 & & & \\
\hline
\end{tabular}

Anova test will be applied in order to understand whether emotional intelligence and life satisfaction differs by departments. Anova test results will be used to determine whether there is a difference between the answers given to the emotional intelligence and life satisfaction scale among departments. The main hypothesis of the analysis asserts that there is no difference between departments. The possibility value calculated after the test (Sig) was found to be higher than 0.05 excluding only two factors. The main hypotheses of these two factors will be rejected. The results are as follows;

- The factor of evaluating others' feelings doesn't differ by department.

- The factor of evaluating one's own feelings differs by department. The mean of those studying in coaching education is the highest and the lowest value belongs to those studying in sports management.

- The factor of regulating emotion doesn't differ by department.

- The factor of social skills differs by department. The mean value of those studying in physical education and sports is the highest and the lowest value belongs to sport management students.

- The factor of using feelings doesn't differ by department.

- The factor of life satisfaction doesn't differ by department.

Table 11. Descriptive Analyses for the Variable of Department

\begin{tabular}{l|l|l|l}
\hline \multirow{2}{*}{ Dimensions } & \multicolumn{3}{c}{ Mean } \\
\cline { 2 - 4 } Evaluating Others' Feelings & $\begin{array}{c}\text { Coaching } \\
\text { education }\end{array}$ & $\begin{array}{c}\text { Physical education } \\
\text { and sports teaching }\end{array}$ & $\begin{array}{c}\text { Sports } \\
\text { management }\end{array}$ \\
\hline Evaluating One's Own Feelings & 16.72 & 17.21 & 16.53 \\
\hline Regulating Emotions & 11.56 & 10.68 & 10.27 \\
\hline Social Skills & 7.54 & 7.68 & 7.47 \\
\hline Using Feelings & 10.59 & 10.74 & 9.64 \\
\hline Life Satisfaction & 21.28 & 22.34 & 21.33 \\
\hline
\end{tabular}

The mean values regarding the variable of departments are observed in Table 11.

Table 12. Jonckheere-Terpstra Test by the Variable of Grade

\begin{tabular}{l|l|l|l|l|l|l}
\hline & $\begin{array}{c}\text { Evaluating } \\
\text { Others' } \\
\text { Feelings }\end{array}$ & $\begin{array}{c}\text { Evaluating One's Own } \\
\text { Feelings }\end{array}$ & $\begin{array}{c}\text { Regulating } \\
\text { Emotions }\end{array}$ & \multicolumn{1}{|l|}{ Social Skills } & Using Feelings & $\begin{array}{c}\text { Life } \\
\text { Satisfaction }\end{array}$ \\
\hline $\begin{array}{l}\text { Number of Levels in } \\
\text { your class }\end{array}$ & 4 & 4 & 4 & 4 & 4 & 4 \\
\hline $\mathrm{N}$ & 292 & 292 & 292 & 292 & 292 & 292 \\
\hline Observed J-T Statistic & 14294.000 & 16452.000 & 14394.000 & 15050.000 & 14842.000 & 15312.000 \\
\hline Mean J-T Statistic & 15650.000 & 15650.000 & 15650.000 & 15650.000 & 15650.000 & 15650.000 \\
\hline $\begin{array}{l}\text { Std. Deviation of J-T } \\
\text { Statistic }\end{array}$ & 795.051 & 788.603 & 785.961 & 789.204 & 796.681 & 798.906 \\
\hline Std. J-T Statistic & -1.706 & 1.017 & -1.598 & -.760 & -1.014 & -.423 \\
\hline Asymp. Sig. (2-tailed) & .088 & .309 & .110 & .447 & .310 & .672 \\
\hline
\end{tabular}


Jonckheere-Terpstra test will be applied to determine whether emotional intelligence and life satisfaction scale differs by the sports branches. Jonckheere-Terpstra test results will be used to determine whether there is a difference between the answers given to the emotional intelligence and life satisfaction scale among sports branches. The main hypothesis of the analysis asserts that there is no difference between sports branches. The possibility value calculated after the test (Sig) was found to be higher than 0.05 for all factors. The main hypotheses of all factors cannot be rejected. The results are as follows;

- The factor of evaluating others' feelings doesn't differ by grade.

- The factor of evaluating one's own feelings doesn't differ by grade.

- The factor of regulating emotion doesn't differ by sports branches.

- The factor of social skills doesn't differ by grade.

- The factor of social skills doesn't differ by grade.

- The factor of using feelings doesn't differ by grade.

- The factor of life satisfaction doesn't differ by grade.

Table 13. Descriptive Analyses for the Variable of Grade

\begin{tabular}{|c|c|c|c|c|}
\hline \multirow[b]{2}{*}{ Dimensions } & \multicolumn{4}{|c|}{ Mean } \\
\hline & 1 & 2 & 3 & 4 \\
\hline Evaluating Others' Feelings & 16.64 & 18.43 & 16.30 & 16.38 \\
\hline Evaluating One's Own Feelings & 10.00 & 11.17 & 11.48 & 10.56 \\
\hline Regulating Emotions & 7.12 & 7.90 & 8.00 & 7.13 \\
\hline Social Skills & 10.32 & 10.57 & 10.65 & 9.91 \\
\hline Using Feelings & 21.56 & 23.30 & 21.41 & 20.80 \\
\hline Life Satisfaction & 16.60 & 15.90 & 16.74 & 16.31 \\
\hline
\end{tabular}

The mean values regarding the variable of grade are observed in Table 13.

Table 14. Correlation Analysis for Emotional Intelligence Scale and Life Satisfaction Scale

\begin{tabular}{llrr}
\hline & & Life dimension & Emotional intelligence \\
\hline \multirow{3}{*}{ Life dimension } & Pearson Correlation & 1 & -.084 \\
& Sig. (2-tailed) & & .154 \\
& $\mathrm{~N}$ & 292 & 292 \\
Emotional intelligence & Pearson Correlation & -.084 & 1 \\
& Sig. (2-tailed) & .154 & \\
& $\mathrm{~N}$ & 292 & 292 \\
\hline
\end{tabular}

H0: There isn't a relation between emotional intelligence and life satisfaction.

H1: There is a relation between emotional intelligence and life satisfaction.

Looking at Table 14, it is seen that there isn't a relation between emotional intelligence and life satisfaction. Thus, H0 hypothesis is accepted.

\section{Discussion}

The purpose of this study is to compare emotional intelligence levels of students studying in 2017-2018 summer school of Balıkesir University School of Physical Education and Sports with their life satisfaction by some demographic characteristics.

Success in sports activity depends on athlete morphology, intellectual qualities and emotional characteristics. Physiological and functional features, tactical knowledge and theoretical knowledge can be thought to form an equation with emotional intelligence (Lozovina et al. 2012).

Examining the emotional intelligence and life satisfaction by the age variable, the factor of using emotions is observed to be highest in the 18-21 age group. This result shows that women who have just reached adulthood use their feelings better. Analyzing the life satisfaction factor by the variable of age, 26+ age group is observed to have the highest level. In other words, women who are young adults have recently realized themselves and have entered a productive period. This has increased their life satisfaction. Looking at the literature, it shows parallelism with the thesis of Roitman (1999), Dal (2015) and Goleman (2014) stating that "emotional intelligence maintains a life-long development" and similar results have been obtained in the study analyzing the relation between emotional intelligence and life satisfaction in women. However, it has been found in the study of Diener \& Lucas, (1999); Lucas \& Gohm (2000) that life satisfaction doesn't differ by the variable of age. 
Analyzing the factor of evaluating one's own feelings by the department studied, it has been observed that mean values in those studying in coaching department are higher than those studying in other departments. Since coaches are the leaders of teams. Thus, they constantly make self-criticism and improve themselves because they hold themselves responsible for the success or failure of the team. It has also been concluded that the factor of social skills by the variable of department is high in those studying in physical education and sports teaching. High mean scores of social skills in the students studying in physical education and sports department indicate that they act in accordance with the environment in social situations, they are confident, they can interpret the feelings of others correctly and fully and they can empathize, they are friendly individuals who are capable of initiating and directing conversations in a social or any other subject. This result complies with the study of Avşar (2004).

No significant relation has been ascertained between emotional intelligence and life satisfaction. This result doesn't comply with the studies conducted by Deniz and Yilmaz (2004), Ardahan (2012) and Koçak and İçmenoğlu (2012).

Looking at emotional intelligence and life satisfaction by the variable of grade, no significant difference has been found. According to our results, students who have just started university and senior students have similar characteristics in terms of emotional intelligence. This can be interpreted in a way that the grade studied doesn't make a positive contribution to the emotional intelligence skills of students. However, even though the sources of the problems are different, the university freshmen and those who are newly graduated often face many problems during their university education. Freshmen face problems related to accommodation, making friends, adapting to the new environment and problems related to academic issues while graduate students have problems in finding a job related to graduation. The lack of difference between the two groups in terms of emotional intelligence may be caused by the different problems they experience. This result conforms to the studies performed by Deniz and Yilmaz (2004) ve Kizil (2012) about emotional intelligence levels of university students.

\section{Conclusion}

In conclusion, it has been established that there isn't any difference in the dimension of evaluating others' feelings and regulating emotions among the participants by age, sports branch, department and grade. The difference has been observed in the dimension of using feelings by age and in the dimensions of evaluating one's own feelings and social skills by department. Life satisfaction has been found to differ by age. The fact that there isn't a relationship between emotional intelligence and life satisfaction levels of the participants is among our conclusions.

\section{References}

Adiloğulları, İ., \& Görgülü, R. (2015). An Application Study of Emotional Intelligence Survey in Sports, Spor, Egzersiz. ve Antrenman Bilimleri Dergisi, 1(2), 83-94.

Ardahan, F. (2012), Analysis on the Relation between Emotional Intelligence and Life Satisfaction in the Example of Those Doing Outdoor Sports, Pamukkale Journal of Sport Sciences, 3(3), 20-33.

Avşar, Z. (2004). Determining the Social Skill Levels of Physical Education and Sports Teachers, Eğitim Fakültesi Dergisi, XVII(2), 111-130.

Çetinkaya, Ö., \& Alparslan, A. M. (2011). The Effect of Emotional Intelligence on Communication Skills: A Research on University Students. Süleyman Demirel University, Faculty of Economics and Administrative Sciences Journal, 16(1), 363-377.

Dal, E. (2015). Analysis on the Relation between Emotional Intelligence Level and Life Satisfaction in Women. Üsküdar University Department of Clinical Psychology, Master's Thesis.

Deniz, M. E., \& Y1lmaz, E. (2004). The Relation between Emotional Intelligence Skills of University Students and Their Life Satisfaction, XIII. Ulusal Eğitim Bilimleri Kurultayı Abstracts (6-9 July 2004) Malatya, İnönü University.

Diener, E. (1984), Subjective Well-Being, Psychological Bulletin, 95(3), 542-575. https://doi.org/10.1037/0033-2909.95.3.542

Diener, E., \& Lucas, R. E. (1999). Personality and subjective well-being. In D. Kahneman, E. Diener, \& N. Schwarz (Eds.), Well-being: The foundations of hedonic psychology (pp. 213-229). New York: Russell-Sage.

Diener, E., Emmons, A. E., Larsen, R. J., \& Griffin. S. (1985). The Satisfaction With Life Scale. Journal of Personality Assessment, 49(1), 71-75. https://doi.org/10.1207/s15327752jpa4901_13

Durak, M., Durak, Ş. E., \& Gencoz, T. (2010). Psychometric properties of the Satisfaction with Life Scale among Turkish university students, correctional officers, and elderly adults. Social Indicators Research, 99(3), 413-429. https://doi.org/10.1007/s11205-2010-9589-4

Goleman, D. (1996). EmotionalIntelligence: Why It Can MatterMoreThan IQ, Bloomsbury. 
Goleman, D. P. (2014), Why Is Emotional Intelligence More Important Than IQ?, B. Seçkin Yüksel (Translator), İstanbul: Varlık Yayınları.

Haime, J. (2011). The Value of Emotional Intelligence for High Performance Coaching, International Journal of Sports Science\&Coaching, 6(3). https://doi.org/10.1260/1747-9541.6.3.337

Harrod, N. R., \& Scheer, S. D. (2005). An Explanation of Adolescent Emotional Intelligence in Relation to Demographic Characteristics. Adolescence, 40(159), 503-512.

Jones, M. (2003). Controllingemotions in sport. The Sport Psychologist, 17, 471-486. https://doi.org/10.1123/tsp.17.4.471

Kızıl, Z. (2012). Analysis on Emotional Intelligence of the Students in Faculty of Educational Sciences in Terms of Different Variables. Unpublished Master's Thesis. Ankara University Institute of Educational Sciences, Ankara.

Koçak, R., \& İçmenoğlu, E. (2012). The Interpretive Role of Emotional Intelligence and Creativity Levels of Gifted Students on Their Life Satisfaction, Türk Psikolojik Danışma ve Rehberlik Dergisi, 4(37), 73-85.

Lane, A. M., Meyer, B. B., Devonport, T. J., Kevin, A. D., Thelwell, R., Gill, G. S., ... Weston, N. (2009). Validation of the emotional intelligence scale for use in sport. Journal of Sport Science and Medicine, 8, 289-295.

Lopes, P. N. (2004). Emotional Intelligence and Social Interaction. Personality and Social Psychology Bulletin, 30, 1018-1034. https://doi.org/10.1177/0146167204264762

Lozovina, M., Bonacin, D., \& Lozovina, V. (2012). Emotional Intelligence and Determination of Sociometric Status in Sport, Sport Science, 5(2), 66-74.

Lucas, R. E., \& Gohm, C. L. (2000). Age and sex differences in subjective well being across cultures. E. Diener \& E. M. Suh (Eds.) Culture and subjective well being (pp. 291-298) Cambridge, MA: MIT Press

Malinauskas, R., \& Vazne, Z. (2014). Emotional Intelligence among Lithuanian and Latvian Student Athletes, Education Physical Training Sport Social Sciences, 2(93), 29-33.

Özer, M., \& Karabulut, Ö. Ö. (2003), Life Satisfaction in Elderly, Turkish Journal of Geriatrics, Geriatri, 6(2), 72-74.

Roitman, J. D. (1999), Emotional Intelligence: The Heart is Smarter than the Brain, Boulder: University of Colorado.

Schutte, N. S., Malouff, J. M., Hall, L. E., Haggerty, D. J., Cooper, J. T., Golden, C. J., \& Dornheim, L. (1998). Development and validation of a measure of emotional intelligence. Personality and Individual Differences, 25, 167-177. https://doi.org/10.1016/S0191-8869(98)00001-4

Szabo, A., \& Urbán, F. (2014). Do Combat Sports Develop Emotional Intelligence, Kinesiology 46(1), 53-60.

Tuğrul, C. (1999). Duygusal Zekâ (Emotional Intelligence), Klinik Psikiyatri, 1, 12-20.

Veenhoven, R. (1996), Is Happiness Relative?, Social Indicators Research, 24, 1-34. https://doi.org/10.1007/BF00292648

Yetim, Ü. (2003). The impacts of individualism/collectivism, self-esteem and feeling of mastery on life satisfaction among the Turkish University students and academicians. Social Indicators Research, 61(3), 297-317. https://doi.org/10.1023/A:1021911504113

\section{Copyrights}

Copyright for this article is retained by the author(s), with first publication rights granted to the journal.

This is an open-access article distributed under the terms and conditions of the Creative Commons Attribution license which permits unrestricted use, distribution, and reproduction in any medium, provided the original work is properly cited. 